\title{
New physical and chemical perspectives on the ecology of Thorea hispida (Thoreaceae)
}

\author{
Rossano BOLPAGNI, ${ }^{*}$ Carolina AMADIO,${ }^{2}$ Emily T. JOHNSTON,${ }^{3}$ Erica RACCHETTI ${ }^{1}$ \\ ${ }^{1}$ Department of Life Sciences, University of Parma, V.le G.P. Usberti 11/A, 43124 Parma, Italy; ${ }^{2}$ Department of Environmental Biology, \\ La Sapienza University of Rome, P.le A. Moro 5, 00185 Rome, Italy; ${ }^{3}$ Department of Environmental \& Plant Biology, Ohio University, \\ Porter Hall 315, 45701 Athens, OH, USA \\ *Corresponding author: rossano.bolpagni@unipr.it
}

\begin{abstract}
In the last decade, many new records for Thorea hispida (Thore) Desvaux 1898 emend. Sheath, Vis et Cole 1993 (Rhodophyta) have been collected from Europe as a probable result of the enactment of the Water Framework Directive which has fueled a renewed interest in the characterization of the macroscopic primary producers of river systems. Despite this, the species remained poorly documented, especially regarding habitat requirements and related physical and chemical drivers. To further add to the knowledge of these parameters, a three-year survey (2009-2011) was conducted along the southern reach of the Oglio River, a mid-size tributary of the Po River in Northern Italy that hosts three newly recorded populations of T. hispida. In parallel, a comprehensive review of the literature was performed. In this work, we present the first records for T. hispida from Italy, and a first detailed physical, chemical and hydromorphological characterization of its habitat. We confirm the predilection of T. hispida for turbid waters (>80 $\mathrm{mg} \mathrm{L}^{-1}$ of total suspended solids) with high nutrient (up to $9.4 \mathrm{mg} \mathrm{L^{-1 }}$ for nitrates and up to $173 \mu \mathrm{g} \mathrm{L}^{-1}$ for soluble reactive phosphorous) and conductivity levels (up to $\left.660 \mu \mathrm{S} \mathrm{cm}^{-1}\right)$. In addition, our data extended the range of tolerance of the species for temperature (5.1-26.2 $\left.{ }^{\circ} \mathrm{C}\right)$ and $\mathrm{pH}(7.1-8.6)$. In general, our results and previously published data corroborate with the idea that $\mathrm{T}$. hispida can not be considered a sensitive species (i.e., a taxon scarcely adapted to increasing levels of pollution), showing a preference for rivers characterized by high nutrients availability. Moreover, its rarity must be traced to the low detectability of the thallus due to species life cycle and the very limited accessibility of colonized habitats.
\end{abstract}

Key words: Autoecology, eutrophication, freshwater red algae, rarity, Thoreales, turbid rivers.

Received: July 2014. Accepted: October 2014.

\section{INTRODUCTION}

Many new records for Thorea hispida (Thore) Desvaux (Rhodophyta) have been collected in recent years from Europe (for Serbia, Simić and Pantović, 2010; Simić et al., 2014; for Lithuania, Vitonyte, 2011; for Rumania, Cărăuş, 2012; for Spain, Tomás et al., 2013). This is likely a result of the enactment of the Water Framework Directive that imposed an overall review and updating of knowledge on neglected macroscopic primary producers in freshwater ecosystems such as red algae (Ceschin et al., 2012, 2013). Despite this renewed interest, the species remains poorly documented, especially regarding its ecological preferences (Vitonytè, 2011; García and Aboal, 2014).

Generally, the freshwater Thoreales are more common in tropical and subtropical areas (Sheath and Hambrook, 1990; Sheath et al., 1993; Carmona and Necchi, 2001) and are considered rare and threatened in Europe (Eloranta et al., 2011). Accordingly, T. hispida is included in the Algae Red List in some European countries (Ludwig and Schnittler, 1996; Shelyag-Sosonko, 1996; Sieminska, 2006; Simić et al., 2007; Temniskova et al., 2008; Täuscher, 2010), and it is still considered a species with a very restricted distribution (García and Aboal, 2014 and references therein). At present, there is not an agreement among researchers working with this taxon about the habitat conditions of the species. Haury et al. (2006) have proposed the species as a good proxy of mesotrophic/oligotrophic conditions and with very limited ecological amplitude in the calculation of the IBMR index (Macrophyte Biological Index for Rivers), developed for defining the river's trophic status. Other authors have reported the species in habitats characterized by turbid and nutrient-rich waters (Rott et al., 1999; Carmona and Necchi, 2001; Tomás et al., 2013; García and Aboal, 2014). A possible explanation of this discrepancy could be i) the complexity of the biological cycle of the species that includes the Chantransia sporophyte stage, which is difficult to identify, or/and ii) the habitats in which this species exists are poorly investigated (Higa et al., 2007). In general, the macroalgal communities of large lowland and turbid rivers are little known due to the logistical difficulty to sample these habitats on a regular basis (Ceschin et al., 2010, 2012; Simić et al., 2014). Consequently, we argue that this 
species is considered rare because it is difficult to detect or because it colonizes neglected habitats; accordingly, the supposed sensitivity to pollution of the species is the probably result of its low detectability.

In order to verify this hypothesis and to clarify the environmental ranges of the species, the present work provides new environmental data for T. hispida, which is reported for the first time in Italy in the Oglio River, a mid-size, regulated and nutrient-rich tributary of the Po River (Northern Italy). Hence, a seasonal monitoring study was conducted during 2009-2011 at 8 sampling stations in a $40 \mathrm{~km}$ stretch of the Oglio River, which hosts three T. hispida populations. The algal samples were complemented by river water samples and water discharge measurements. Our findings were then compared with the available literature.

\section{METHODS}

\section{Study area}

The study area was about a $40 \mathrm{~km}$ length of the Oglio River and was located in the central portion of the Po River alluvial basin (Northern Italy) (Fig. 1). The local climate is continental, with mean annual temperature of $\sim 13^{\circ} \mathrm{C}$ and precipitation close to $800 \mathrm{~mm}$; the bioclimatic region for the study area is within the mesaxeric region. The Oglio River catchment is heavily exploited for agricultural and farming practices with arable lands representing up to $60 \%$ of the basin area. A large nitrogen $(\mathrm{N})$ surplus characterizes the arable lands resulting in widespread $\mathrm{N}$ pollution of sur-

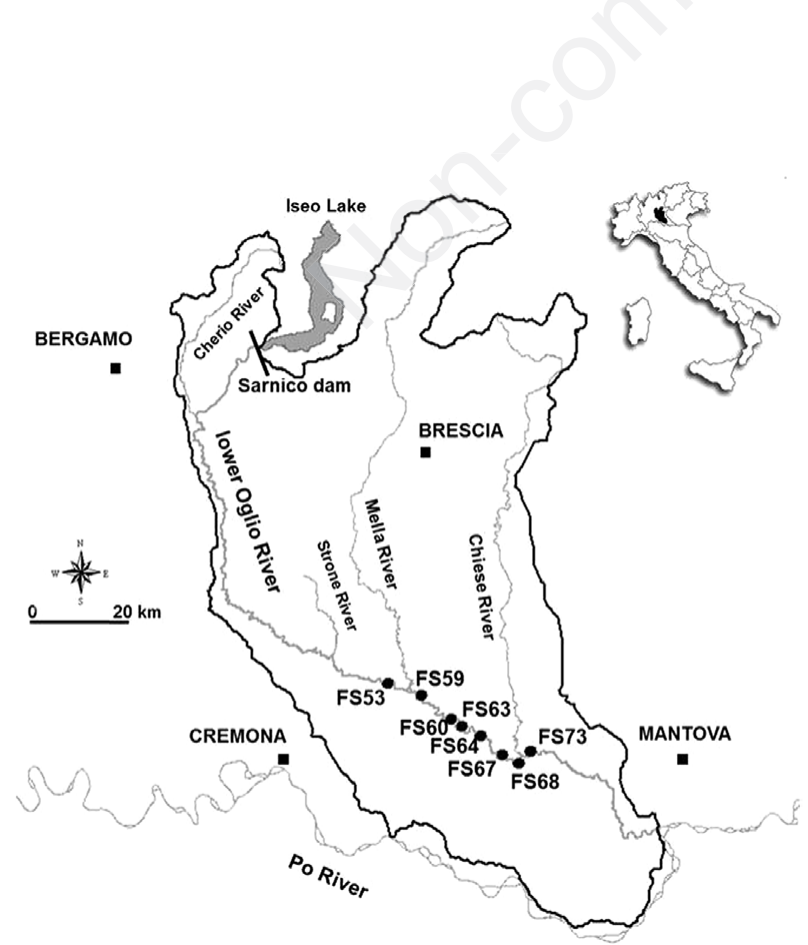

Fig. 1. Lower Oglio River Basin and sampling stations. face and ground waters (Soana et al., 2011). A complex system of dams, water extraction structures and levees allows control of the Oglio River discharges and limits the erosional/depositional processes that characterize natural watercourses. The effects of these multiple pressures are evident in terms of water quality and quantity. The lower reach of the Oglio River is characterized by nitrate-rich and turbid waters and, during the summer, upstream water diversion results in a prolonged low-discharge phase (late May to September; Bartoli et al., 2012).

\section{Thorea hispida sampling and molecular analysis}

Thorea hispida samples were first collected near Ostiano in 2009 (sampling site FS59) and near Binanuova and Calvatone in 2010 (sampling sites FS53 and FS73) (Figs. 1 and 2). All populations were sampled again and confirmed in 2010 (FS59) and 2011 (FS48, FS59, FS73). In general, the algal coverage of the river's bottom ranged between $1 \%$ and $5 \%$ (by visual assessment).

T. hispida specimens were collected by hand and a portion was immediately fixed in $4 \%$ formaldehyde in the field and then stored in the collection of the Dept. of Life Sciences of the Parma University (Italy). Fresh and fixed specimens were examined using a Leica DM750 microscope equipped with a Leica DFC 295 digital camera; the morphological characterization was conducted according to Sheath et al. (1993), Carmona and Necchi (2001), and Eloranta et al. (2011). Sub-samples collected at site FS48 were dried in silica gel and stored at $-20^{\circ} \mathrm{C}$ for DNA analysis that was performed at Ohio University. Molecular sequence data were generated for the $r b c \mathrm{~L}$ (chloroplast) gene. Molecular data confirmed the attribution of the present populations to T. hispida (a more detailed analysis and description of molecular analyses and results were reported by Johnston, 2012). A general morphological illustration of Italian specimens was provided in Fig. 3.

\section{Water quality, hydromorphological and biological characterization}

Oglio River waters were characterized over 3 years with a seasonal periodicity (early December, January-February, late April-early June, late July-mid August; n=12) at 8 sampling stations. Temperature, conductivity, dissolved oxygen, and $\mathrm{pH}$ were measured in situ with a multiple probe (YSI model 556 MPS); water samples (2 L) were collected using a plastic bottle just below the water surface. Samples for DIC (dissolved inorganic carbon) were transferred in glass vials (Exetainer, Labco, High Wycombe, UK). Samples for $\mathrm{NH}_{4}^{+}$(ammonium) and $\mathrm{NO}_{3}^{-}$(nitrate) determinations were filtered through Whatman GF/F glass fiber filters (Ø 47 $\mathrm{mm}$, porosity $0.45 \mu \mathrm{m}$ ) and transferred to plastic vials; samples for SRP (soluble reactive phosphorous) were filtered and kept in glass vials. Water subsamples were transferred 
to plastic vials to measure TN and TP (total nitrogen and total phosphorus). All water samples and $1.5 \mathrm{~L}$ of water for each station were kept to $4^{\circ} \mathrm{C}$ and transferred to the laboratory. DIC samples were immediately titrated with $0.1 \mathrm{~N} \mathrm{HCl}$ (Anderson et al., 1986); total suspended solids were measured by filtration through a pre-dried and weighed glass fiber filter GF/F (Whatman, UK, Ø $25 \mathrm{~mm}$ and $0.45 \mu \mathrm{m}$ ) (APHA, 1998); chlorophyll- $a$ was determined by filtration through a glass fiber filter GF/F (Whatman, UK, Ø $47 \mathrm{~mm}$ and porosity $0.45 \mu \mathrm{m}$ ) and by overnight extraction in cold 90\% aqueous acetone (APHA, 1998). $\mathrm{NH}_{4}^{+}, \mathrm{NO}_{3}^{-}, \mathrm{NO}_{2}^{-}$, TN, SRP and TP were determined with standard spec- trophotometric methods according to Rodier (1978), Valderrama (1981), and APHA (1998).

During the study period, simultaneously with the water quality characterization, hydromorphological data were also collected (kindly supplied by the Consorzio dell'Oglio). River flow and current velocity measurements were performed using the Rio Grande ADCP (Acoustic Doppler Current Profiler). A visual assessment of the shading was also performed by examining the percentage of water surface shaded by riparian vegetation at the maximum solar radiation (10:00 to 14:00). Data on the composition of aquatic primary producer communities were
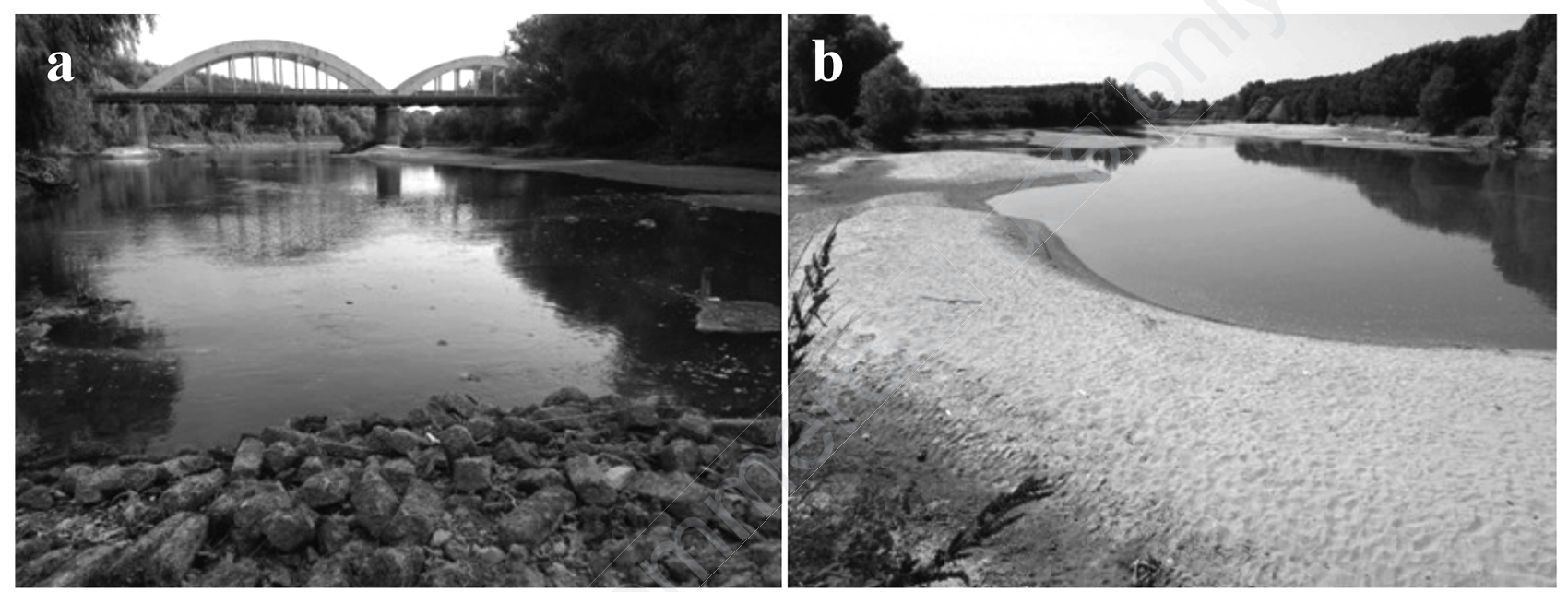

Fig. 2. A general overview of the sampling stations FS59 (a) and FS73 (b).
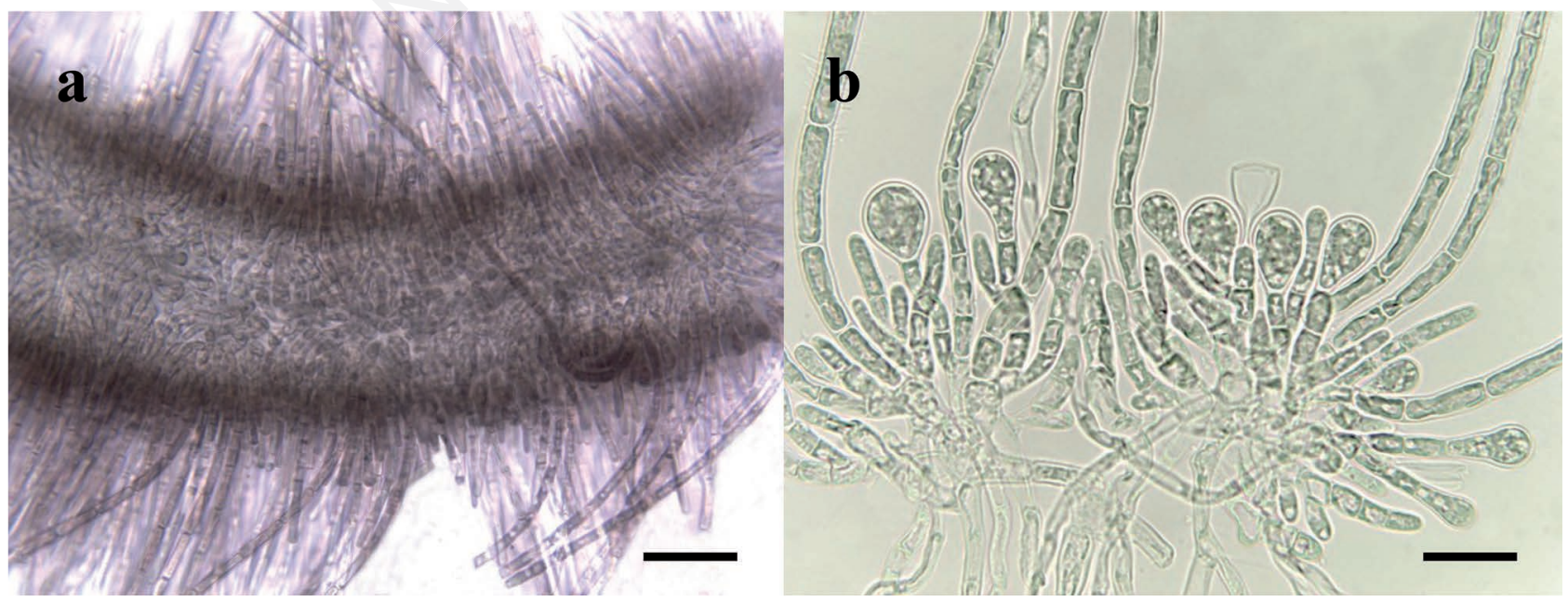

Fig. 3. Morphological features of Thorea hispida. a) Aspects of a middle portion of a plant showing the copious assimilatory filaments not enclosed in a common mucilage; scale bar: $100 \mu \mathrm{m}$. b) Monosporangia attached to colorless medullar filaments; scale bar: $20 \mu \mathrm{m}$. 
collected during the summer sampling, with exception of stations FS64 and FS67 which were very close to the stations FS63 and FS68. As a result, we consider the information collected within these stations (FS63 and FS68) representative of the nearby ones.

\section{RESULTS}

T. hispida was found at three sites (FS53, FS59, FS73; Fig. 1, Tab. 1) in river sections characterized by variable widths, depths, and shading: 40-85 m width, 0.3-1.0 m depth, and with rates of shading ranging between $5-15 \%$. Thalli were collected from different substrata, including stones, bricks, concrete blocks, waste material, and submerged tree branches. In general, $T$. hispida colonized hard substrata and artificial structures such as submerged roadbeds, bridge pilings and artificial levees. Current velocity ranged from 0.3 to $1.7 \mathrm{~m} \mathrm{~s}^{-1}$ with discharges of 20 to $180 \mathrm{~m}^{3} \mathrm{~s}^{-1}$. In 2011, the river stretch experienced numerous flood events such that river flows reached peaks greater than $260 \mathrm{~m}^{3} \mathrm{~s}^{-1}$, which were associated with much higher current velocity rates than typical. During summer months, canopy shading varied between 0\% (at FS59) and $15 \%$ (at FS48). The associated species were typical of mesotrophic to eutrophic conditions. Among algae and aquatic plants, Cladophora glomerata (Linnaeus) Kützing 1843, Oscillatoria spp., Spirogyra spp., Ceratophyllum demersum L., Myriophyllum spicatum L. and Lemnaceae were the most common taxa (Tab. 1).

The river water conditions varied greatly (Fig. 4). Temperatures displayed wide fluctuations ranging between $26.2^{\circ} \mathrm{C}$ (FS73) measured in late July-mid August and $5.1^{\circ} \mathrm{C}$ measured in December. Overall, annual mean values were between 13.2 and $14.3^{\circ} \mathrm{C}$. The mean values of $\mathrm{pH}$ ranged from 7.9 to 8.0 units. Only site FS53 showed a maximum value of $8.6 \mathrm{pH}$ units. Conductivity was generally high, ranging between 314 and $660 \mu \mathrm{S} \mathrm{cm}^{-1}$, typical of eutrophic rivers located across hyper-exploited flood plains. Maximum dissolved oxygen concentrations were always greater than $100 \%$ of saturation with 3 -yrs means ranging between 92 and 96\%. Mean dissolved inorganic carbon was $\sim 4 \mathrm{mM}$, with a maximum of $5.7 \mathrm{mM}$ at sites FS73; mean total suspended solids increased from 18.6 $\mathrm{mg} \mathrm{L}^{-1}$ at FS53 up to $29.2 \mathrm{mg} \mathrm{L}^{-1}$ at FS73, with a peak equal to $99.0 \mathrm{mg} \mathrm{L}^{-1}$ at FS63 in early December 2009. $\mathrm{NH}_{4}{ }^{+}$concentrations were less variable among sites and seasons, ranging between 0.01 and $0.50 \mathrm{mg} \mathrm{L}^{-1}$; 3-yrs mean value above $0.2 \mathrm{mg} \mathrm{L}^{-1}$ was found only at site FS64. On the contrary, the $\mathrm{NO}_{3}^{-}$content was one order of magnitude higher and reached values up to $9.4 \mathrm{mg} \mathrm{L}^{-1}$, representing the largest portion of the total nitrogen content: on average, $\mathrm{NO}_{3}^{-}$accounted for $86 \%$ of TN. Mean SRP concentrations for each station were moderately variable and generally higher than $50 \mu \mathrm{g} \mathrm{L}^{-1}$. At FS59, FS60, FS68, and FS73, SRP concentrations reached maximum values up to $100 \mu \mathrm{g} \mathrm{L}^{-1}$. As well, TP concentrations varied from 13.1 to $194.4 \mu \mathrm{g} \mathrm{L}^{-1}$ and showed a trend increasing from FS53 to FS73 similar to the TSS concentrations. Water column chlorophyll $a$ concentrations were low, ranging between 0.5 and $8.1 \mu \mathrm{g} \mathrm{L}^{-1}$; mean values ranged from 3.0 to $3.4 \mu \mathrm{g} \mathrm{L}^{-1}$ (Tab. 2).

\section{DISCUSSION}

The present data confirm the propensity of the species Thorea hispida to inhabit rivers characterized by eutrophic conditions with high nutrients (nitrate and soluble reactive phosphorous), conductivity, and turbidity ( $>80$ mg TSS L ${ }^{-1}$ ) (Davis-Colley and Smith, 2001; Tomás et al., 2013; García and Aboal, 2014). Indeed, the Oglio River is a medium-size temperate lowland river, flowing through the Po alluvial basin that is one of the most productive areas of the Northern Hemisphere (Bassanino et al., 2011). Specifically, the Oglio River catchment is characterized by a positive $\mathrm{N}$ budget, which indicates an $\mathrm{N}$ surplus on arable land due to an excess of $\mathrm{N}$ input by manure and fertilizers compared to crop demand. At the basin scale, the net $\mathrm{N}$ export at the river basin closing section is calculated to be $13000 \mathrm{t} \mathrm{N} \mathrm{y}^{-1}$ corresponding to $12 \%$ of the total $\mathrm{N}$ inputs (Soana et al., 2011; Bartoli et al., 2012). Locally, this $\mathrm{N}$ excess generated a widespread pollution of nitrate in surface and ground waters as a secondary effect of the extreme permeability of the soils in the catchment. This translates into a considerable availability of solutes and nutrients in the water that increases along the course of the river, reaching maximum values in the last river stretch where we found the T. hispida populations (up to $9.4 \mathrm{mg} \mathrm{L}^{-1}$ for $\mathrm{NO}_{3}^{-}$; up to $173 \mu \mathrm{g} \mathrm{L}^{-1}$ for SRP; up to $660 \mu \mathrm{S} \mathrm{cm}^{-1}$ for conductivity and up to $99 \mathrm{mg} \mathrm{L}^{-1}$ for TSS) (Bartoli et al., 2012; Delconte et al., 2014).

Numerous reports of environmental parameters for collections of T. hispida from around the world exist in the literature (e.g., Simić and Pantović, 2010; Vitonytè, 2011; Tomás et al., 2013; Garcia and Aboal, 2014). The comparison between data from literature and data from this study shows much variation in ecological preferences of T. hispida (Tab. 2). In the Oglio River, the "Chantransia" sporophyte stage of T. hispida tolerates and survives at cold temperatures (during the winter, temperatures not exceeding $7.4^{\circ} \mathrm{C}$ and with a minimum of $5.1^{\circ} \mathrm{C}$ ) and neutral $\mathrm{pH}$ (7.1), which are the lowest values respect to those reported in literature for the species (Tab. 2). Overall, $T$. hispida exhibits preference for neutral to alkaline $(\mathrm{pH} \sim 7$ $8.6)$, moderate to well-oxygenated waters $(80-140 \%$ of oxygen saturation), and water temperate $\left(\sim 14.0-26.0^{\circ} \mathrm{C}\right)$ (Sheath et al., 1993; Carmona and Necchi, 2001; Tomás et al., 2013; García and Aboal, 2014). Simić and Pantović (2010). Simić et al. (2014) reported a very restricted conductivity range of $428-480 \mu \mathrm{S} \mathrm{cm}^{-1}$ for the Serbian populations in Sava River, and this range was close to the 


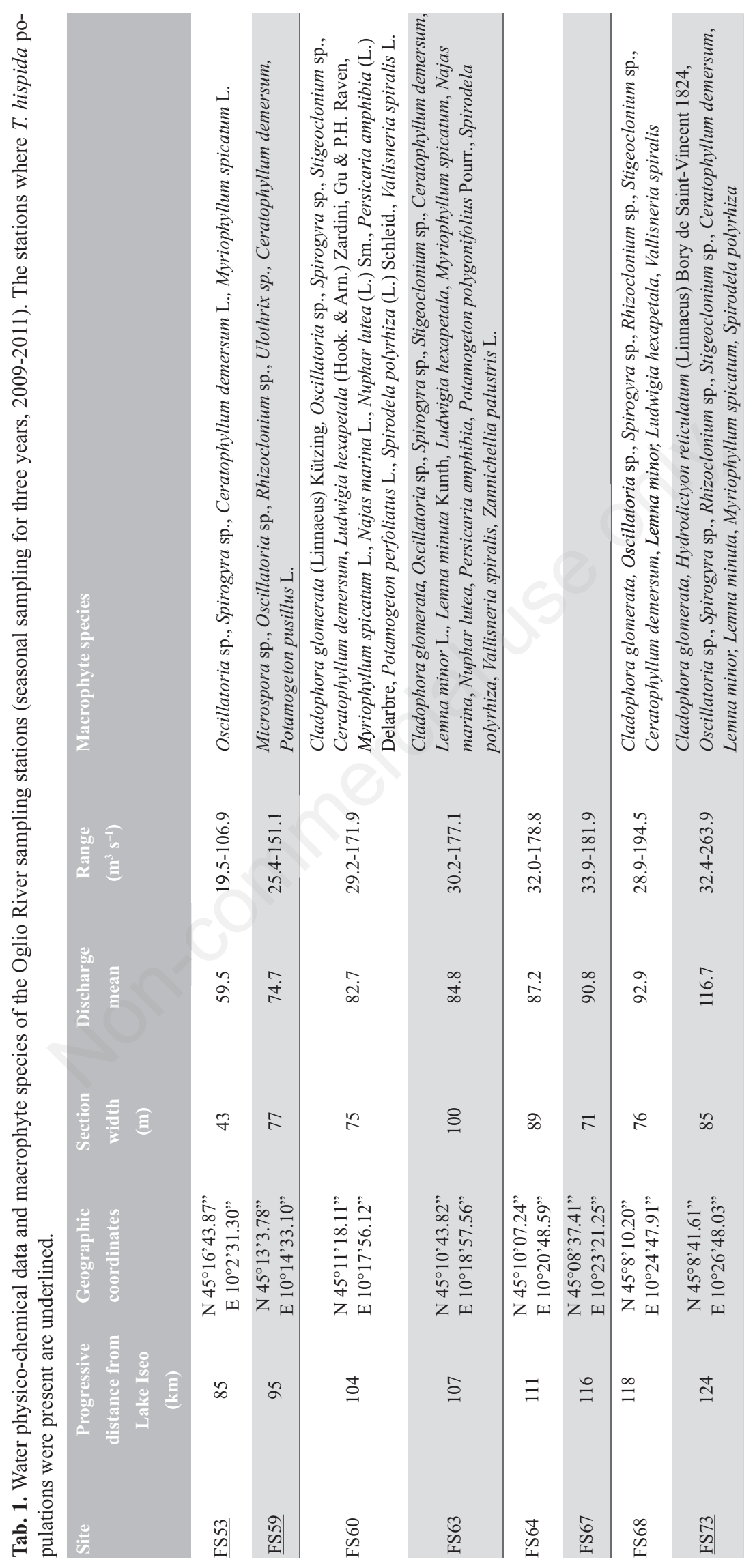


upper values recorded by Sheath et al. (1993) in North America (180-500 $\left.\mu \mathrm{S} \mathrm{cm}^{-1}\right)$. Stations where T. hispida was found in the River Oglio had a similar conductivity range (314-660 $\mu \mathrm{S} \mathrm{cm}^{-1}$ ). However, Carmona and Necchi (2001) measured values up to $2140 \mu \mathrm{S} \mathrm{cm}^{-1}$ for the Mexican populations (stream Micos) and Tomás et al. (2013) reported a range of $\sim 500-2500 \mu \mathrm{S} \mathrm{cm}^{-1}$ for the Ebro River basin (North-East Spain). Recently, García and Aboal (2014), investigating a Mediterranean marsh (PegoOliva), recorded the highest values of conductivity (2110$6300 \mu \mathrm{S} \mathrm{cm}^{-1}$ ). With respect to nutrient concentrations, $\mathrm{NH}_{4}{ }^{+}$values measured in the Oglio River water were the
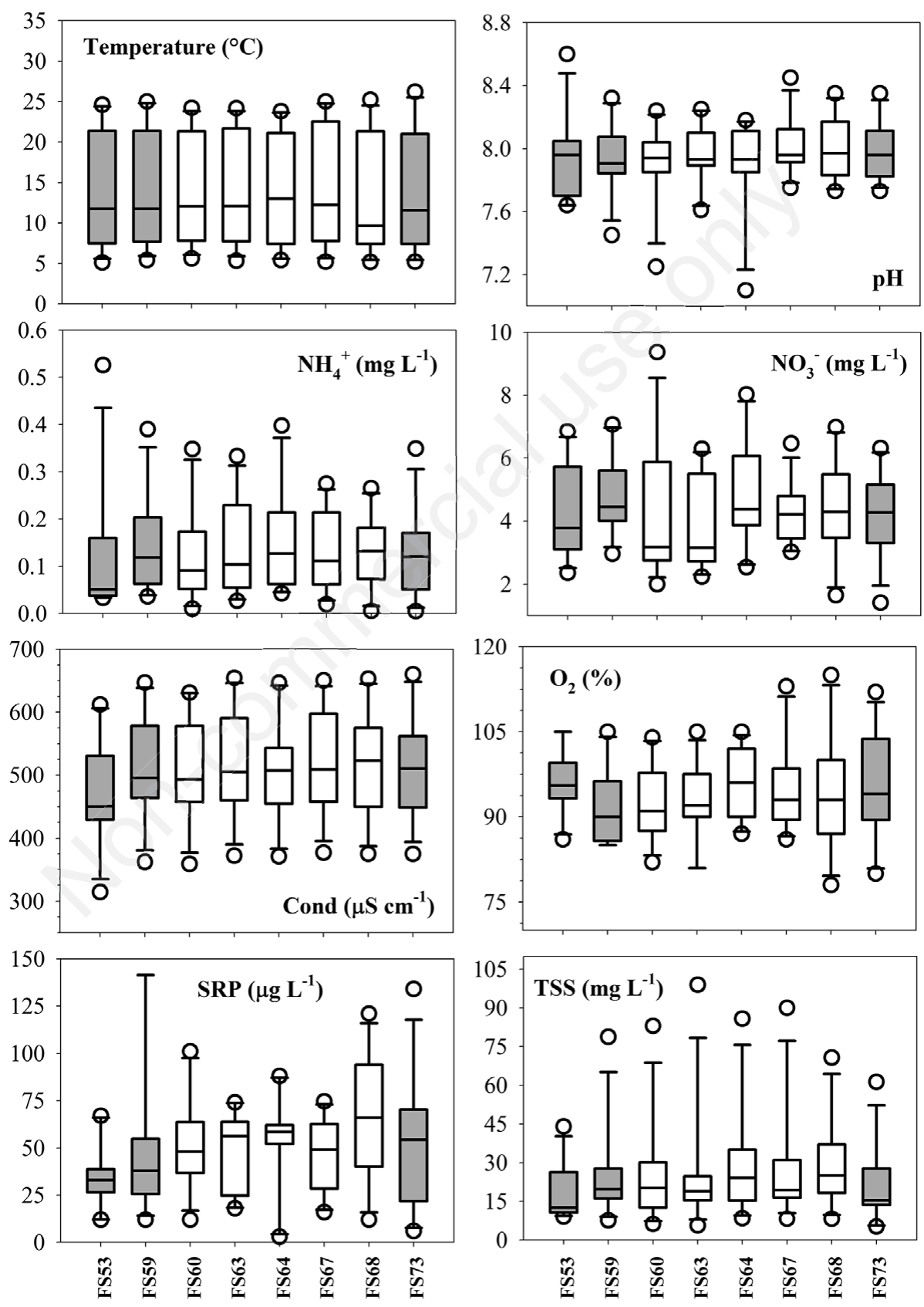

Fig. 4. Range of the water physico-chemical parameters measured seasonally for a period of three years (2009-2011, $\mathrm{n}=12)$ in the lower Oglio River stretch; in grey are Oglio River sites where T. hispida populations were present. T, temperature; $\mathrm{pH}$; Cond, conductivity at $20^{\circ} \mathrm{C} ; \mathrm{O}_{2}$, percentage of dissolved oxygen; $\mathrm{NH}_{4}^{+}$, ammonium; $\mathrm{NO}_{3}^{-}$, nitrate; TN, total nitrogen; SRP, soluble reactive phosphorus; TSS, total suspended solids. 
Tab. 2. Environmental data (physico-chemical and hydromorphological variables) of rivers where Thorea hispida populations were collected.

\begin{tabular}{|c|c|c|c|c|c|c|c|c|c|c|c|c|}
\hline Reference & & Study area & $\begin{array}{c}\mathrm{T} \\
\left({ }^{\circ} \mathrm{C}\right)\end{array}$ & $\mathrm{pH}$ & $\begin{array}{l}\text { Cond } \\
\left(\mu \mathrm{S} \mathrm{cm} \mathrm{cm}^{-1}\right)\end{array}$ & $\begin{array}{c}\mathrm{O}_{2} \\
\left(\mathrm{mg} \mathrm{L}^{-1}\right)\end{array}$ & $\begin{array}{c}\mathrm{NH}^{4+} \\
\left(\mathrm{mg} \mathrm{L}^{-1}\right)\end{array}$ & $\begin{array}{c}\mathrm{NO}^{3-} \\
\left(\mathrm{mg} \mathrm{L}^{-1}\right)\end{array}$ & $\begin{array}{c}\text { SRP } \\
\left(\mathrm{mg} \mathrm{L}^{-1}\right)\end{array}$ & $\begin{array}{c}\mathrm{CV} \\
\left(\mathrm{m} \mathrm{s}^{-1}\right)\end{array}$ & $\begin{array}{l}\text { Depth } \\
\text { (m) }\end{array}$ & $\begin{array}{l}\text { Width } \\
\text { (m) }\end{array}$ \\
\hline Sheath et al., 1993 & range & N America & $18.0-24.0$ & $7.5-8.3$ & $180-500$ & & & & & $0.1-1$ & & \\
\hline $\begin{array}{l}\text { Carmona and Necchi, } \\
2001\end{array}$ & $\begin{array}{l}\mathrm{m} \pm \mathrm{sd} \\
\mathrm{m} \pm \mathrm{sd} \\
\text { range }\end{array}$ & $\begin{array}{c}\text { Mexico } \\
\text { Brazil }\end{array}$ & $\begin{array}{c}24.1 \pm 1.7 \\
18.7 \pm 0.8 \\
17.6-28.0\end{array}$ & $\begin{array}{l}7.4 \pm 0.3 \\
7.7 \pm 0.1 \\
7.0-8.0\end{array}$ & $\begin{array}{c}1280 \pm 453 \\
170 \pm 178 \\
59-2140\end{array}$ & & & & & $\begin{array}{l}0.3 \pm 0.1 \\
0.3 \pm 0.1 \\
0.2-0.4\end{array}$ & $\begin{array}{c}0.3 \pm 0.2 \\
0.1 \pm 0.1 \\
<0.5\end{array}$ & \\
\hline Simić and Pantović, 2010 & $\begin{array}{l}\mathrm{m} \pm \mathrm{sd} \\
\text { range }\end{array}$ & Serbia & $23.2 \pm 0.8$ & $8.2 \pm 0.1$ & $453 \pm 26$ & & & & & $0.5-0.7$ & $0.2-2$ & $10-650$ \\
\hline Vitonytė, 2011 & $\begin{array}{l}\mathrm{m} \pm \mathrm{sd} \\
\text { range }\end{array}$ & Lithuania & $\begin{array}{l}12.1 \pm 3.7 \\
9.4-19.5\end{array}$ & $\begin{array}{l}8.1 \pm 0.2 \\
7.8-8.2\end{array}$ & $\begin{array}{l}553 \pm 15 \\
530-568\end{array}$ & & $\begin{array}{c}0.07 \pm 0.04 \\
0.0-0.13\end{array}$ & $\begin{array}{l}1.1 \pm 0.6 \\
0.2-1.8\end{array}$ & $\begin{array}{l}0.04 \pm 0.01 \\
0.03-0.05\end{array}$ & $0.4 \pm 0.2$ & $0.20-2$ & \\
\hline Tomás et al., 2013 & range & Spain & $14.0-26.0$ & $7.5-8.4$ & $\sim 400-2500$ & $\sim 5.0-11.5$ & $\sim 0.03-0.13$ & $\sim 5.0-17.0$ & $\sim 0.01-0.80$ & & $0.1-1$ & \\
\hline García and Aboal, 2014 & range & Spain & $17.8-22.6$ & & $2110-6300$ & $7.7-9.9$ & $0.01-0.11$ & $15.7-27.4$ & $0.02-0.04$ & & & \\
\hline This study & $\begin{array}{l}\mathrm{m} \pm \mathrm{sd} \\
\text { range }\end{array}$ & Italy & $\begin{array}{l}14.3 \pm 6.8 \\
5.1-26.2\end{array}$ & $\begin{array}{l}8.0 \pm 0.2 \\
7.1-8.6\end{array}$ & $\begin{array}{c}510 \pm 81 \\
314-742\end{array}$ & $\begin{array}{l}9.8 \pm 1.7 \\
7.3-13.2\end{array}$ & $\begin{array}{l}0.13 \pm 0.10 \\
0.01-0.53\end{array}$ & $\begin{array}{l}4.5 \pm 1.6 \\
1.4-9.4\end{array}$ & $\begin{array}{l}0.05 \pm 0.03 \\
0.03-0.17\end{array}$ & $0.5-0.7$ & $0.3-1$ & $45-85$ \\
\hline
\end{tabular}

T, temperature; Cond, Conductivity; $\mathrm{O}_{2}$, dissolved oxygen; $\mathrm{CV}$, current velocity; $m \pm s d$, mean \pm standard deviation.

highest among those reported (up to $0.53 \mathrm{mg} \mathrm{L}^{-1}$ ) for river ecosystems. However, $\mathrm{NO}_{3}{ }^{-}$values were closer to those measured by Tomás et al. (2013) in Ebro River basin and lower than those measured by García and Aboal (2014) in the Pego-Oliva marsh (Tab. 2). Concentrations of SRP exhibited a range from 0.03 to $0.17 \mathrm{mg} \mathrm{L}^{-1}$ according to ranges found by Tomás et al. (2013) and García and Aboal (2014). In summary, the populations of T. hispida from Italy grow in lowland river reaches characterized by elevated conductivity, turbidity and nutrients levels, confirming environmental ranges found by Tomás et al. (2013) and observations provided by Rott et al. (1999), Carmona and Necchi (2001). Similarly, our hydromorphological data support the preference of the Italian $T$. hispida for river sections analogous to range reported by Simić and Pantović (2010) and by Tomás et al. (2013) (Tab. 2). With respect to preferred substrata and sites of colonization by this species, our observations are similar to those reported in the literature with the Italian populations of $T$. hispida growing on hard substrata, both natural and artificial (e.g., stones and bricks) at unshaded sites (Carmona and Necchi, 2001; Simić and Pantović, 2010; Tomás et al., 2013).

\section{CONCLUSIONS}

These results confirm the preference of T. hispida for rivers for relatively high levels of nitrogen and phosphorous, conductivity and turbidity. Our sampling sites displayed the highest values of ammonium among those reported in literature (up to $0.53 \mathrm{mg} \mathrm{L}^{-1}$ ); whereas all other investigated parameters are consistent with the available literature, especially in terms of water current velocity (0.1-1.0 $\left.\mathrm{m} \mathrm{s}^{-1}\right)$, maximum depth of colonization $(0.1-2.0$ $\mathrm{m})$, conductivity $\left(59-6300 \mu \mathrm{S} \mathrm{cm}^{-1}\right)$, and nitrate content (1.4-23.4 $\mathrm{mg} \mathrm{L}^{-1}$ ). On the basis of this evidence, we argue that $T$. hispida cannot be considered a threatened taxon, and its rarity, in other words the low level of reported observations of the species worldwide, may be mainly attributed to i) its life cycle that makes the species scarcely detectable, and ii) the often limited accessibility of colonized habitats. Bearing all this in mind, the high discharges and connected high turbidity levels make the study of macroscopic primary producers in these habitats difficult. It is no coincidence that, for river ecosystems, the enactment of the WFD resulted in an exponential increase in the detection of species that were previously considered rare, including T. hispida (Simić and Pantović, 2010; Vitonytè, 2011; Cărăuş, 2012; Tomás et al., 2013). Further investigations are necessary to clarify the distribution patterns of $T$. hispida, but nonetheless we have information that allows us to exclude a risk of imminent local extinction. On the contrary, we can consider the species as a tolerant taxon.

\section{ACKNOWLEDGMENTS}

This research was supported by Consorzio dell'Oglio (Lombardy Region) in the frame of the project Evaluation of the Vital Minimum Flow of the Oglio River (20092012). We are grateful to Ing. M. Buizza for the technical and field support, and to Prof. N. Abdelahad from La Sapienza University of Rome for the assistance in the morphological investigation of Italian Thorea hispida samples. Dr. Morgan Vis from Ohio University is thanked for her contribution to the confirmation of the molecular identification of Thorea hispida and her editorial comments on an early version of the manuscript. 


\section{REFERENCES}

Anderson LG, Hall POJ, Iverfeldt A, Van der Loeff MMR, Sundby B, Westerlund SFG, 1986. Benthic respiration measured by total carbonate production. Limnol. Oceanogr. 31:319-329.

APHA, AWWA, WEF, 1998. Standard methods for the examination of water and wastewater. 20. APHA: $1360 \mathrm{pp}$.

Bartoli M, Racchetti E, Delconte CA, Sacchi E, Soana E, Laini A, Longhi D, Viaroli P, 2012. Nitrogen balance and fate in a heavily impacted watershed (Oglio River, Northern Italy): in quest of the missing sources and sinks. Biogeosciences 9:361-373.

Bassanino M, Sacco D, Zavattaro L, Grignani C, 2011. Nutrient balance as a sustainability indicator of different agro-environments in Italy. Ecol. Indic. 11:715-723.

Cărăuş I, 2012. Algae of Romania. A distributional checklist of actual algae, ver. 2.3, $3^{\text {rd }}$ rev. University of Bacau Publ.: 809 pp.

Carmona JJ, Necchi Jr. O, 2001. Systematics and distribution of Thorea (Thoreaceae, Rhodophyta) from central Mexico and south-eastern Brazil. Phycol. Research 49:231-239.

Ceschin S, Bisceglie S, Ricci S, 2012. Contribution to the knowledge of red algae (Rhodophyta) of some rivers in Central Italy. Cryptogamie Algol. 31:61-67.

Ceschin S, Ricci S, Abati S, Bisceglie S, Minciardi MR, Zuccarello V, 2013. Distribution and ecology of red algae in Italian rivers. Fund. Appl. Limnol. 183:223-337.

Ceschin S, Ricci S, Bisceglie S, 2010. A first study of the algal flora of the Tiber River basin (Italy). Cryptogamie Algol. 31:273-285.

Davis-Colley RJ, Smith DG, 2001. Turbidity, suspended sediment, and water clarity: a review. J. Am. Water Resour. As. 37:1085-1101.

Delconte CA, Sacchi E, Racchetti E, Bartoli M, Mas-Pla J, Re $\mathrm{V}, 2014$. Nitrogen inputs to a river course in a heavily impacted watershed: a combined hydrochemical and isotopic evaluation (Oglio River Basin, N Italy). Sci. Total Environ. 466-467:924-938.

Eloranta P, Kwandrans J, Kusel-Fetzmann E, 2011. Rhodophyceae and Phaeophyceae, p. 1-155. In: M. Schagerl (ed.), Süßwasserflora von Mitteleuropa. 7. G. Fischer.

García ME, Aboal M, 2014. Environmental gradients and macroalgae in Mediterranean marshes: the case of PegoOliva marsh (East Iberian Peninsula). Sci. Total Environ. 475:216-224.

Haury J, Peltre M.-C, Trémolières M, Barbe J, Thiébaut G, Bernez I, Daniel H, Chatenet P, Haan-Archipof G, Muller S, Dutartre A, Laplace-Treyture C, Cazaubon A, LambertServien E, 2006. A new method to assess water trophy and organic pollution - the Macrophyte Biological Index for Rivers (IBMR): its application to different types of river and pollution. Develop. Hydrobiol. 190:153-158.

Higa A, Kasai F, Kawachi M, Kumano S, Sakayama H, Miyashita, Watanabe MM, 2007. Seasonality of gametophyte occurrence, maturation and fertilization of the freshwater red alga Thorea okadae (Thoreales, Rhodophyta) in the Kikuchi River, Japan. Phycologia 46:160-167.
Johnston ET, 2012. The systematic revision of the freshwater red algal order Thoreales (Nemaliophycidae, Rhodophyta). Master's Thesis, Ohio University, USA.

Ludwig G, Schnittler M, 1996. [Rote liste gefährdeter Pflanzen Deutschlands].[Book in German]. Bundesamt fur Naturschutz: $744 \mathrm{pp}$.

Rott E, Pfister P, van Dam H, Pall K, Pipp E, Binder N, Ortler K, 1999. [Indikationslisten für Aufwuchsalgen. Teil 2: Trophieindikation und autökologische Anmerkungen, Bundesministerium für Land- und Forstwirtschaft].[Book in German]. Wasserwirtschaftskataster: 248 pp.

Sheath RG, Hambrook JA, 1990. Freshwater ecology, p. 423453. In: K.M. Cole and R.G. Sheath (eds.), Biology of the red algae. Cambridge University Press.

Sheath RG, Vis ML, Cole KM, 1993. Distribution and systematics of the freshwater red algal family Thoreaceae in North America. Eur. J. Phycol. 28:231-41.

Shelyag-Sosonko YR, 1996. [The red data book of Ukraine].[Book in Ukrainian]. Ukrayins'ka Encyklopediya: 603 pp.

Simienska J, 2006. Red list of the algae of Poland, p. 37-52. In: Z. Mirek, K. Zarzycki, W. Wojewoda and Z. Szelag (eds.), Red list of plants and fungi in Poland. Polish Academy of Sciences.

Simić SB, Đorđević NB, Vasiljević BM, 2014. New record of red alga Thorea Hispida (Thore) Desvaux (Rhodophyta) in the River Sava (Sremska Mitrovica, Serbia). Water Res. Manage. 4:47-52.

Simić S, Pantović N, 2010. Observations on the rare alga Thorea hispida (Thore) Desvaux (Rhodophyta) from Serbia. Cryptogamie Algol. 31:343-353.

Simić V, Simić S, Paunović M, Cakić P, 2007. Model of assessment of critical risk of extinction and the priorities of protection of endangered aquatic species at national level. Biod. Conserv. 16:2471-2493.

Soana E, Racchetti E, Laini A, Bartoli M, Viaroli P, 2011. Soil budget, net export and potential sinks of nitrogen in the lower Oglio River watershed (northern Italy). Clean-Soil Air Water 39:956-965.

Täuscher L, 2010. [Prodromus einer Roten Liste der Cyanobakterien/Blaualgen, Rot-, Gelbgrün-, Braun- und Grünalgen des Landes Brandenburg - Ergebnisse eines bibliographischen Überblicks zur Algen-Besiedlung, p. 511-515].[Article in German]. In: Proc. 2009 Conf. German Society of Limnology, Hardegsen, Germany.

Temniskova D, Stoyneva PM, Kirjakov KI, 2006. Red list of the Bulgarian algae. I. Macroalgae. Phytol. Balcan. 14:193-206.

Tomás P, Moreno JL, Aboal M, Oscoz J, Durán C, Navarro P, Elbaile A, 2013. [Distributión y ecología de algunas especies de rodofitos (Rhodophyta) en la Cuenca del río Ebro].[Article in Spanish]. Limnetica 32:61-70.

Valderrama JC, 1981. The simultaneous analysis of total nitrogen and total phosphorus in natural waters. Mar. Chem. 10:109-122.

Vitonytė I, 2011. First record of red algae Thorea hispida in Lithuanian freshwaters. Bot. Lith. 17:165-175. 